\title{
BASKETBALL LEARNING MODEL DEVWELOPMENT THROUGH MLM (MOBILE LEARNING MEDIA) BASED ON ANDROID
}

\author{
*Andi Nur Abady, Devi Catur Winata, \\ Correspondence: STOK Bina Guna, Medan, Indonesia \\ E-mail: andi.nurabady@gmail.com
}

\begin{abstract}
The long-term goal of this research is that it is expected to be able to overcome the problems that have occurred so far in the world of education, especially physical education that occurs in the field of basketball material, whether it is in the form of teaching methods for teachers/lecturers who are always monotonous so that students are not interested in sports lessons on basketball material or facilities and infrastructure that are not provided at school/on campus so that this research can be the answer to every problem that occurs in the field, significantly the problem increases with the Covid-19 pandemic, where the learning method changes from face to face to online, Therefore, this researcher provides a solution by learning through Android-based MLM (Mobile Learning Media).

The specific purpose of this research is to develop a basketball learning model with an Android-based MLM (Mobile Learning Media) system that launches a basketball learning application via Android that can be downloaded by anyone and makes learning easier. With the development of this method, it is hoped that it can provide solutions to teachers/lecturers, especially basketball lecturers, in providing material to students during the current pandemic.
\end{abstract}

\section{Keywords: Basketball Learning Model, Mobile Learning}

\section{Journal Physical Education. Health and Recreation \\ Introduction}

Advances Advances in science and technology in the world of education are very influential in providing new contributions and insights in the form of learning to students, especially students of sports, physical education, health and recreation at Sekolah Tinggi Olahraga dan Kesehatan (STOK) Bina Guna Medan in basketball courses. In the learning process, the KKNI curriculum is implemented by STOK Bina Guna Medan to meet national curriculum standards and is responsible for producing productive human resources in their fields. The biggest challenge faced today is balancing technology in the learning process with methods and approaches.

The research method or design used to develop Android-based Mobile Learning Media (MLM) in Basketball Courses is research and development

PJKR 
$(\mathrm{RnD})$. Research and development services validate and develop products according to research needs (Sugiyono, 2016:28).

Basketball course is a compulsory subject followed by health and recreation physical education students wherein this course students are given experience about skills and regulations in basketball games. Problems that arise when students take the Final Examination with skills and cognitive tests at the time of the skills test $80 \%$ of students pass in the implementation. However, when the cognitive test students have common knowledge, only $30 \%$ of the students complete the average. Serious handling efforts are needed in providing knowledge to students in a practical and effective manner so that it can be permanently attached so that not only skills but cognitive skills in basketball courses become better.

The era of digitalization that is currently being faced must be balanced with the education system, especially in the health and recreation physical education lecture system. One of them is using the Mobile Learning Media (MLM) learning media with its product in the form of an application on the android system to improve lecture competence.

\section{Method}

The research design used to develop Android-Based Mobile Learning Media (MLM) in Basketball Courses is research and development (RnD). Research and development services validate and develop products according to research needs (Sugiyono, 2016: 28). The research procedure used is the Thiagarajan theory. Thiagarajan theory uses research and development steps with $4 \mathrm{D}$, namely define, design, development, and dissemination.

Jo urn a Figurẹ 1i Series of Research and Bevelópment Prócèdures e a tion

nubisestis

DEFINE $\longrightarrow$ DESIGN

1. Define: Define or define contains activities to determine what products will be developed, along with their specifications. Defining activities are needs analysis activities carried out through thorough research and literature studies.

2. Design: Design or planning contains activities to make a design for a predetermined product.

3. Development: Development or development contains activities to make a design into a product and test the validity of the product repeatedly until the product is produced in accordance with the specified specifications.

PJKR_

https://jurnal.unimed.ac.id/2012/index.php/jpehr 
4. Dissemination: Dissemination contains activities to disseminate products that have been tested for use by others.

Data analysis is the process of obtaining data as a result of analysis or discussion in FGDs based on the instruments used. Data analysis can be done if the data has been obtained through instruments, while the data analysis techniques carried out are:

1. Observation: observation is the collection of information based on the vision of the researcher or research group. The element of observation is a written record in the form of descriptive data or the researcher's sentences through the observations made on the research subject.

2. Questionnaire: a questionnaire is an instrument to obtain written data from research respondents. The questionnaire used in this research is to use a Likert scale to measure the up-to-dateness of Mobile Learning Media and the Effectiveness of Lecture Media. The questionnaire used a Likert scale.

3. Interviews: interviews are direct data acquisition from research subjects. The researcher asked directly about the product used by the subject. Questions are prepared in advance by the researcher to obtain answers that are by the expectations of the researcher. Questions can develop beyond what was prepared if the purpose of the interview has not been obtained by the researcher.

4. Documentation: documentation is supporting data in the form of documents for lecture teaching materials and student evaluation results.

\section{Result and Discussion}

Before This development, research began on August 20, 2020, with the research subject being 30 -students of STOK Bina Guna. The object in this study is the Mobile Learning Media in basketball learning. The development of Androidbased learning media applications for Basketball learning courses carried out in this study used a development model with a 4D approach (Define, Design, Development, and Dissemination). In detail, the development stages are as follows:

\section{Define}

The define stage is the stage of determining the problem to be raised in this study. At this stage, a needs analysis is carried out as a preliminary research step by conducting observations and interviews. Interviews were conducted with basketball learning lecturers in the STOK Bina Guna campus environment in obtaining the data needed for the design stage.

The data taken in this needs analysis are the unsatisfactory student learning outcomes in the basketball learning course at the mid-semester exam (UTS). From the learning results, cognitively, students have common knowledge, namely $30 \%$ of the average ability, even though the motor performance is inversely 
proportional. This is the basis for researchers to make efforts to provide practical and permanent cognitive knowledge to students.

Design

After going through the next needs analysis stage, the researcher discussed with several education experts about the right solution to the problems at hand. From the results of the discussion, it was concluded that making multimedia-based applications that were practical and easy to access anytime, anywhere. Furthermore, researchers determine the design of the application in question with the stages of determination;

\section{Modelling}

The model in this learning media application uses a thumb focused interaction model or interaction focused on using the thumb (goldengekko: 2014). This model aims to run using one hand without difficulty reaching the menu, as shown in the figure below.

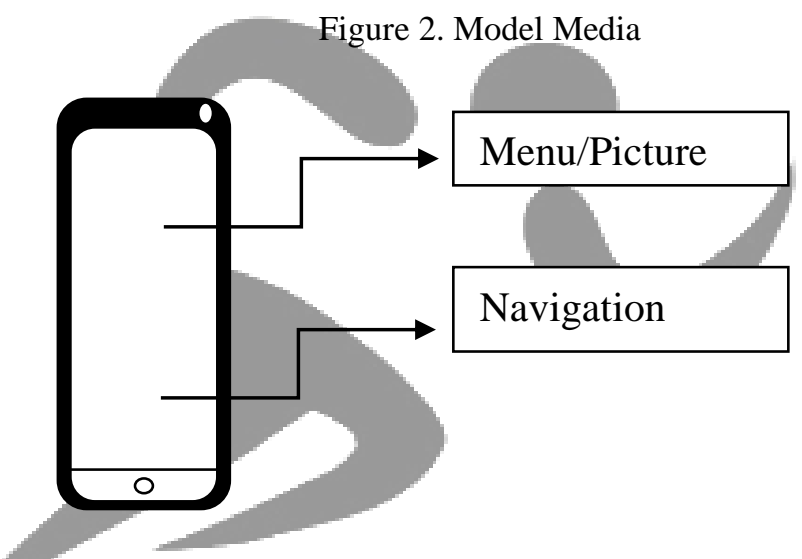

Each control contained in this application will be placed at the bottom of the screen. The goal is that the application can be accessed easily using the thumb. The advantage of using this moder is that it makes navigation easier because the user is not always in a situation where they can use more than one finger to interact with the display. Touch screen or touch gestures are used to open a new layout page.

\section{Content}

The content of the application is in the form of narration and pictures of basic basketball techniques. This application is useful for displaying images, text and videos. Images and text are used to explain the subject matter. The images used are component symbol images, circuit drawings, illustration images and symbol images. While the video is a database stored in the application that will be accessed by users at any time

\section{Development}

The development of the development stage has a goal to produce learning tools that have been revised based on input from experts. This stage design includes:

PJKR_

https://jurnal.unimed.ac.id/2012/index.php/jpehr 
Figure 3. Development Design

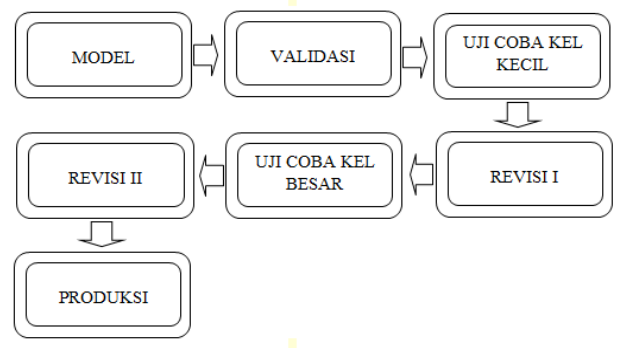

\section{Validation}

Validation is a step or effort to see the feasibility of the application that has been designed in the form of the appearance or content of the application itself. The validation test aims to determine the feasibility of the product before the next step is carried out. The validation test in this study was carried out by four experts, namely two application media experts and two basketball learning lecturers. Validation by experts will produce data and suggestions that are used for software improvement in the first stage, while two basketball learning lecturers will produce data and suggestions in the realm of content/material.

\section{Small-Group Trial}

Small group trials were conducted on other classes that had the same characteristics as the class that was the main subject in this study. The classes taken in this small group trial were students of semester V-A who had received the same material, namely learning Basketball. The implementation of activities in this trial is in the form of distributing an assessment questionnaire on learning media (applications). From this distribution, researchers can take data in the form of the feasibility and effectiveness of the product, which will later be tested on the actual subject.

\section{Revised by experts hysical Education. Health and Recreation}

Experts in this activity are the main key in the perfection of products designed, from the opinions and judgments of competent experts will produce competent products as well. Expert revision is needed after the small group trial activity is carried out to be able to see firsthand the benefits and uses of the developed product.

\section{Large Group Trial}

The next stage is the feasibility test on the actual subject, namely the 30thsemester III-D students. From the several stages that have been passed, the product or learning media will be distributed to students to be tested and assessed for their usefulness, efficiency and practicality in their use.

Revision II by experts

The second revision is the final revision before the product or media is widely distributed. 


\section{Production}

The production stage is the final stage of making media after a series of stages and revisions that have been passed. At this stage, the product/media/application has been declared ready to use and perfect.

Dissemination (distribution/mass production)

The dissemination or disseminate stage is the stage of using tools that have been developed on a wider scale, for example, in other classes on different campuses by different lecturers, which aims to test the effectiveness of using the tools in teaching and learning activities.

\section{Conclusion}

The conclusion of this research is the development of learning media in the form of MLM (Media Learning Mobile) based on Android with applications that have been designed with several uses, both using media and basketball learning experts, with the hopes and objectives of this research in the form of an interesting and interesting learning process. Able to overcome problems that occur in the field, especially with the outbreak of the covid 19 pandemics that is happening at this time so that the learning process takes place online, but learning is still conveyed properly and cooperatively.

\section{References}

Amsikan, S.(2010). Keefektifan pembelajaran matematika dengan model problem based learning dan model cooperative learning type jigsaw di SMP. (Tesis magister, tidak diterbitkan, Universitas Negeri Yogyakarta, Yogyakarta)

Arends, R.I. (2013). Learning to teach:belajar untuk mengajar (9 ${ }^{\text {th }}$ ed). (Terjemahan Helly Prajitno Soetjipto dan Sri Mulyantini Soetjipto). New York:MeGraw Hill Companies Inc.

Coh, $\mathbf{M}_{j}$ et al. (2017). Kinematic and Biodynamic Model of the Long Jump Technique. http://dx.doi.org/10.5772/interchopen.71418

Jojo, I. (2019). Pengaruh Metode Pembelajaran Problem Based Learning Terhadap Hasil Belajar Lompat Jauh Siswa SMK Imanuel 2. Jurnal Pendidikan dan Pembelajaran. Vol 8, No 3 (2019).

Kamnardsiri, T et al. (2015). Knowledge-Based System Framework for Training Long Jump Athletes Using Action Recognition.Journal of Advances in Information Technology Vol.6, No.4, November 2015. doi:10.12720/jait.6.4.182-193.

Kemp, J.E, Morris on G.R, \& M.Ross. (1994). Design effective instruction. New York: Macmillan College Publishing Company.

Muslimin \& Ramadhan, H.P. (2017). Cooperative learning jigsaw and student achievement division teams results of hang style long jump. International Journal of Pysical Education, Sports and Health (ijpesh), 4(3):191-196.

Nitko, A \& Bookhart, S. (2011). Educational assessment of students. (6 $6^{\text {th }}$ ed).United States or America: Pearson Education, Inc.

PJKR_

https://jurnal.unimed.ac.id/2012/index.php/jpehr 
Samsudin. (2008). Pembelajaran Pendidikan Jasmani Olahraga dan Kesehatan SMP/MTs. Penerbit: Litera. Jakarta.

Sugiyono.(2012). Metode Penelitian Kuantitatif, Kualitatif dan R\&D. Bandung: Alfabeta.

Tan, O.S et al. (2009). Problem-based Learning and Creativity. Singapore: Cengage Learning.

Winataputra, U.S. (2013). Menyongsong dan memantapkan implementasi kurikulum 2 013: kebutuhan inovasi dalam pembelajaran. Makalah disajikan dalam Seminar Menyongsong Implementasi Kurikulum 2013, di Universitas Negeri Yogyakarta.

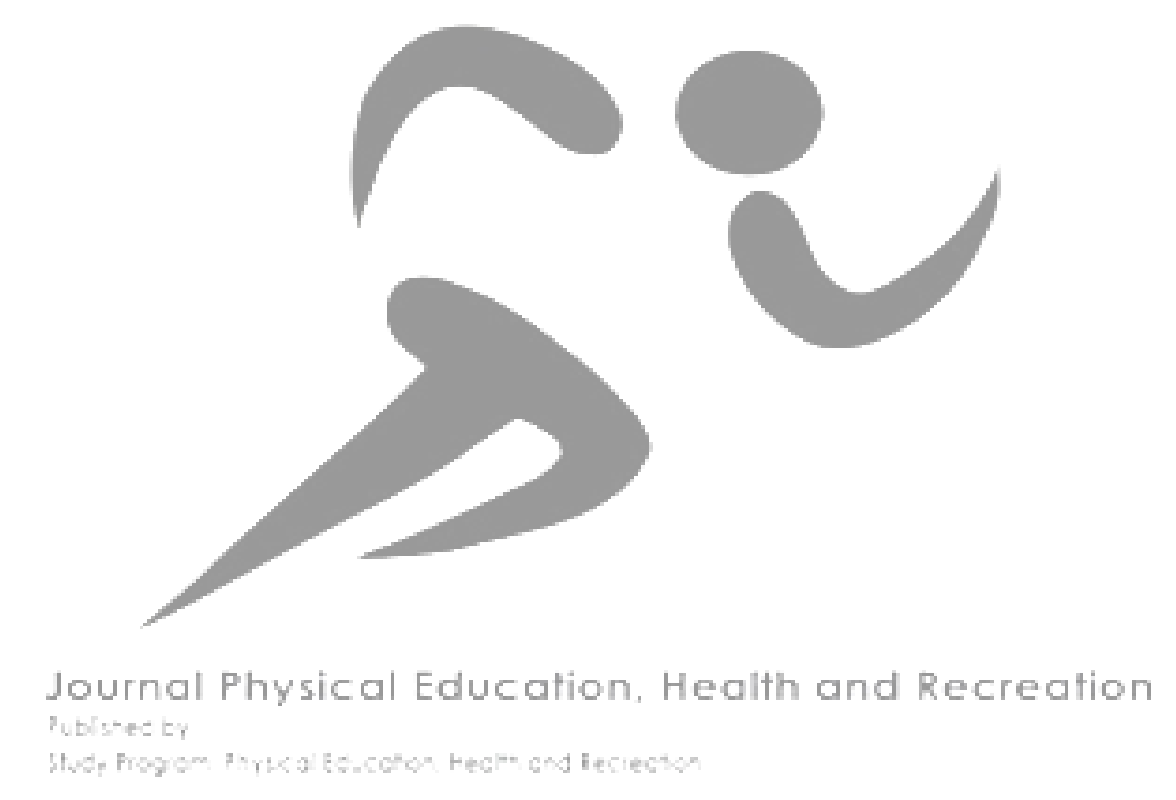

